\title{
Carbachol but Not Acetylcholine Inhibits Contraction by the Protein Kinase C-Dependent and -Independent Pathways in the Smooth Muscle of Guinea Pig Taenia Caeci
}

\author{
Minori Mitsui-Saito and Hideaki Karaki \\ Department of Veterinary Pharmacology, Graduate School of Agriculture and Life Sciences, The University of Tokyo, Bunkyo-ku, Tokyo 113, Japan
}

Received March 6, 1996 Accepted June 7, 1996

\begin{abstract}
In the intestinal smooth muscle of guinea pig taenia caeci, acetylcholine and carbachol induced a transient contraction followed by a sustained contraction. The magnitudes of the transient and sustained contractions were similar when muscle was stimulated with acetylcholine $(0.1 \mu \mathrm{M}-1 \mathrm{mM})$ or a lower concentration $(0.1 \mu \mathrm{M})$ of carbachol. However, higher concentrations of carbachol $(1-100 \mu \mathrm{M})$ induced significantly smaller sustained contraction than the transient contraction. In the $45 \mathrm{mM} \mathrm{KCl}$-stimulated strips, addition of $100 \mu \mathrm{M}$ carbachol induced a transient increase followed by a sustained decrease in the contractile tension. In contrast, acetylcholine $(0.1 \mu \mathrm{M}-1 \mathrm{mM})$ showed only weak inhibitory effects on the high $\mathrm{K}^{+}$-induced contraction either in the absence or presence of a cholinesterase inhibitor, $0.5 \mu \mathrm{M}$ disopropylfluorophosphate. The same concentration of diisopropylfuorophosphate shifted the concentration-response curve for acetylcholine to lower concentrations. In the muscles pretreated with $3 \mu \mathrm{M}$ phorbol 12-myristate 13-acetate for $24 \mathrm{hr}$ to desensitize protein kinase $C$, sustained contractions induced by higher concentrations of carbachol $(1-100 \mu \mathrm{M})$ were significantly greater than those in the strips without the treatment with phorbol ester. However, the transient contraction and the contraction induced by a lower concentration $(0.1 \mu \mathrm{M})$ of carbachol were not changed by the treatment with phorbol ester. Pretreatment with phorbol ester attenuated the inhibitory effect of carbachol on the high $\mathrm{K}^{+}$-induced contraction. These results suggest that the inhibitory effects of carbachol is composed of two phases: protein kinase Cindependent transient inhibition and protein kinase C-dependent sustained inhibition.
\end{abstract}

Keywords: Smooth muscle (intestinal), Acetylcholine, Carbachol, Phorbol ester, Protein kinase C

It has been shown that acetylcholine and carbachol induce contraction by increasing the $\mathrm{Ca}^{2+}$ influx in intestinal smooth muscle (1). Higher concentrations of acetylcholine and carbachol also stimulate phosphoinositide turnover $(2-4)$, and one of the hydrolysis products, inositol 1,4,5-trisphosphate, releases $\mathrm{Ca}^{2+}$ to induce transient contraction (5).

We have previously reported that high concentrations of carbachol inhibit the sustained contraction induced by carbachol itself by a decrease of cytosolic $\mathrm{Ca}^{2+}$ in the intestinal smooth muscle of guinea pig taenia caeci. We have also reported that high concentrations of carbachol inhibit high $\mathrm{K}^{+}$induced contraction (6). Phorbol ester, 12-deoxyphorbol 13-isobutyrate, also inhibited high $\mathrm{K}^{+}$induced contraction, and this effect was abolished when the protein kinase $C$ was desensitized (7). These results suggest that the inhibitory effect of a high concentration of carbachol on high $\mathrm{K}^{+}$-induced contraction may be mediated by the activation of protein kinase $\mathrm{C}$.

To further clarify the physiological role of protein kinase $\mathrm{C}$ in intestinal smooth muscle contraction, we compared the effects of carbachol and acetylcholine on the contractile response in guinea pig taenia caeci. We also examined the contractile and relaxant effects of carbachol in muscle strips in which the protein kinase $\mathrm{C}$ activity had been desensitized.

\section{MATERIALS AND METHODS}

Male guinea pigs, weighing $250-300 \mathrm{~g}$, were killed by a blow on the neck and bled. A section of taenia $(5-10 \mathrm{~mm}$ in length) was dissected from the caecum. For the desensitization of protein kinase $\mathrm{C}$, the muscle strips were incubated in Dulbecco's modified Eagle medium with $10 \%$ fetal calf serum for $24 \mathrm{hr}$ at $37^{\circ} \mathrm{C}$ in a $\mathrm{CO}_{2}$ incubator in the presence of $3 \mu \mathrm{M}$ phorbol 12-myristate 13-acetate or its 
vehicle, $0.3 \%$ dimethylsulfoxide (7).

Normal physiological salt solution contained: 136.9 $\mathrm{mM} \mathrm{NaCl}, 5.4 \mathrm{mM} \mathrm{KCl}, 5.5 \mathrm{mM}$ glucose, $23.8 \mathrm{mM}$ $\mathrm{NaHCO}_{3}, 1.5 \mathrm{mM} \mathrm{CaCl}, 1.0 \mathrm{mM} \mathrm{MgCl}$ and $0.01 \mathrm{mM}$ ethylenediamine-tetraacetic acid. High $\mathrm{K}^{+}$solution was made by adding $\mathrm{KCl}$ to the normal solution. These solutions were aerated with a $95 \% \mathrm{O}_{2}$ and $5 \% \mathrm{CO}_{2}$ mixture at $37^{\circ} \mathrm{C}(\mathrm{pH} 7.4)$. Muscle tension was recorded isometrically with a force-displacement transducer. A passive tension of $2 \mathrm{mN}$ was initially applied, and then tissues were allowed to equilibrate for $60-90 \mathrm{~min}$ until the contractile response to $45 \mathrm{mM} \mathrm{K}^{+}$solution became stable. The magnitude of the high $\mathrm{K}^{+}$-induced contraction in the muscle pretreated with phorbol ester $(5.5 \pm 1.2 \mathrm{mN}, \mathrm{n}=11)$ was not significantly different from that of the vehicle-treated muscle $(4.3 \pm 0.9 \mathrm{mN}, \mathrm{n}=11)$. At the end of an experiment, 12-deoxyphorbol 13-isobutyrate $(1 \mu \mathrm{M})$ was added to the high $\mathrm{K}^{+}$-induced contraction in the strips pretreated with phorbol ester to determine if the contractile effect of phorbol ester had disapeared.

Chemicals used were 12-deoxyphorbol 13-isobutyrate, phorbol 12-myristate 13-acetate (Funakoshi, Tokyo), acetylcholine, carbachol and diisopropylfluorophosphate (Sigma Chemicals, St. Louis, MO, USA).

Results of the experiments are expressed as the mean \pm S.E.M. Student's $t$-test was used for statistical analysis of the results, and $P<0.05$ was considered to be significant.

\section{RESULTS}

Magnitude of the transient and the sustained contractions

In the guinea pig taenia caeci, acetylcholine induced transient contraction followed by sustained contraction. The magnitude of the transient and sustained contractions induced by acetylcholine increased in a concentration-dependent manner, and the magnitude of the sustained contraction measured $20 \mathrm{~min}$ after the addition of acetylcholine was not significantly different from that of the transient contraction (Fig. 1). Carbachol also induced a transient contraction followed by a sustained contraction. The magnitude of the sustained contraction induced by $100 \mathrm{nM}$ carbachol was not significantly different from that of the transient contraction (Fig. 2A). However, the magnitude of the sustained contraction induced by $1 \mu \mathrm{M}$ or higher concentrations of carbachol was significantly smaller than that of the transient contraction (Fig. 2: $B-D)$.

In the presence of cholinesterase inhibitor, $0.5 \mu \mathrm{M} \mathrm{di-}$ isopropylfluorophosphate, contractions induced by lower concentrations of acetylcholine were augmented, shifting the concentration-response curve for acetylcholine to the left (Fig. 1). The magnitude of the sustained contraction

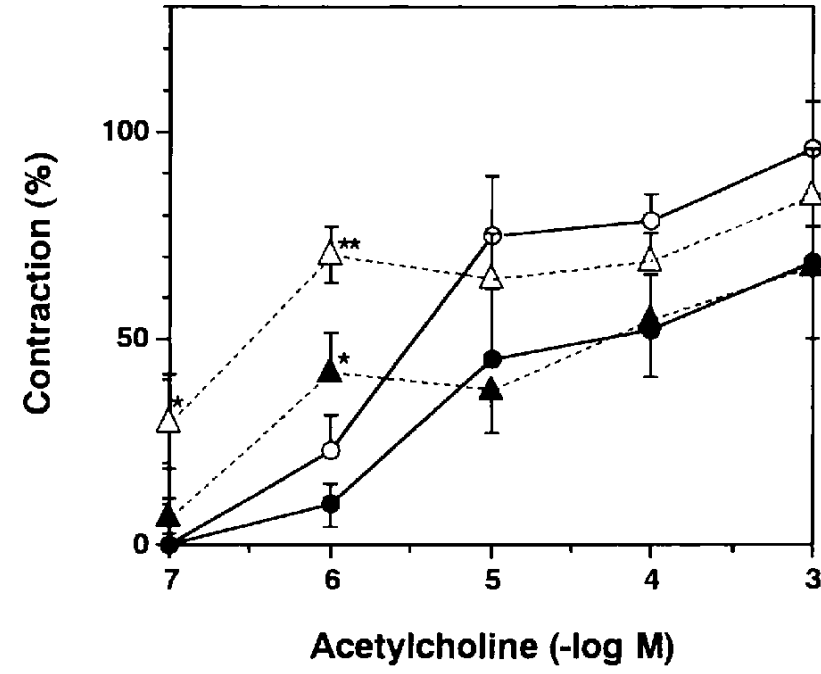

Fig. 1. Concentration-response curves for acetylcholine in the absence and presence of diisopropylfluorophosphate. $\bigcirc$ and $\triangle$ : Acetylcholine-induced transient contraction, $\boldsymbol{O}$ and $\boldsymbol{\Delta}$ : acetylcholine-induced sustained contraction. Diisopropylfluorophosphate $(0.5$ $\mu \mathrm{M}$ ) was added $10 \mathrm{~min}$ before the addition of acetylcholine $(\triangle$ and A). Each point represents the mean \pm S.E.M. of 4-6 experiments. $100 \%$ represents the magnitude of sustained contraction induced by $45 \mathrm{mM} \mathrm{K}^{+} .{ }^{*}$ and ${ }^{* *}$ : Significantly different from the value in the absence of disopropylfluorophosphate with $\mathrm{P}<0.05$ and $\mathbf{P}<0.01$, respectively.

induced by $1 \mu \mathrm{M}$ acetylcholine was smaller than that of the transient contraction $(\mathrm{P}<0.05)$. However, $0.5 \mu \mathrm{M}$ diisopropylfuorophosphate did not change the contractions induced by higher concentrations of acetylcholine. Furthermore, $0.5 \mu \mathrm{M}$ diisopropylfluorophosphate did not modify the carbachol-induced contractions (data not shown).

Effects of acetylcholine and carbachol on high $\mathrm{K}^{+}$-induced contraction

During high $\mathrm{K}^{+}$-induced sustained contraction, addition of $100 \mathrm{nM}$ carbachol induced a slight increase of contraction. Higher concentrations of carbachol (1-100 $\mu \mathrm{M})$ transiently increased and then inhibited the high $\mathrm{K}^{+}$-induced contraction. The inhibition became greater when the concentration of carbachol was increased (Fig. 3).

Acetylcholine also transiently enhanced the high $\mathrm{K}^{+}$induced contraction. However, acetylcholine showed only a small inhibitory effect on high $\mathrm{K}^{+}$-induced contraction at $100 \mu \mathrm{M}-1 \mathrm{mM}$ in the presence or absence of diisopropylfluorophosphate $(0.5 \mu \mathrm{M}$, Fig. 3$)$. Diisopropylfuorophosphate $(0.5 \mu \mathrm{M})$ did not modify high $\mathrm{K}^{+}$induced contractions (data not shown). 
Effects of pretreatment with phorbol ester on acetylcholine- and carbachol-induced contractions

Figure 2 shows the time-courses of the contractions induced by different concentrations of carbachol in the muscle pretreated with phorbol ester. Pretreatment with phorbol 12-myristate 13-acetate did not change the contractions induced by $100 \mathrm{nM}$ carbachol (Fig. 2A). In contrast, pretreatment with phorbol ester changed the contractions induced by higher concentrations (10 and 100 $\mu \mathrm{M})$ of carbachol; carbachol induced a transient contraction followed by an increase of the contraction. Thus, the contraction measured 0.4 to $0.8 \mathrm{~min}$ after the addition of carbachol was smaller, whereas the contraction measured
4 to $10 \mathrm{~min}$ after the addition of carbachol was greater in the muscles pretreated with phorbol ester than the vehicle-treated muscles (Fig. 2: C and D).

Pretreatment with phorbol ester did not change the transient and sustained contractions induced by $100 \mu \mathrm{M}$ acetylcholine (vehicle control: $104.9 \pm 4.9 \%$ and $48.4 \pm 8.2 \%$ of the contraction induced by $45 \mathrm{mM} \mathrm{K}^{+}$, respectively, $\mathrm{n}=4$ each; phorbol ester: $110.3 \pm 28.5 \%$ and $57.0 \pm 5.1 \%$, respectively, $n=4$ each).

Effects of pretreatment with phorbol esters on carbachol-induced inhibition of high $\mathrm{K}^{+}$-induced contraction
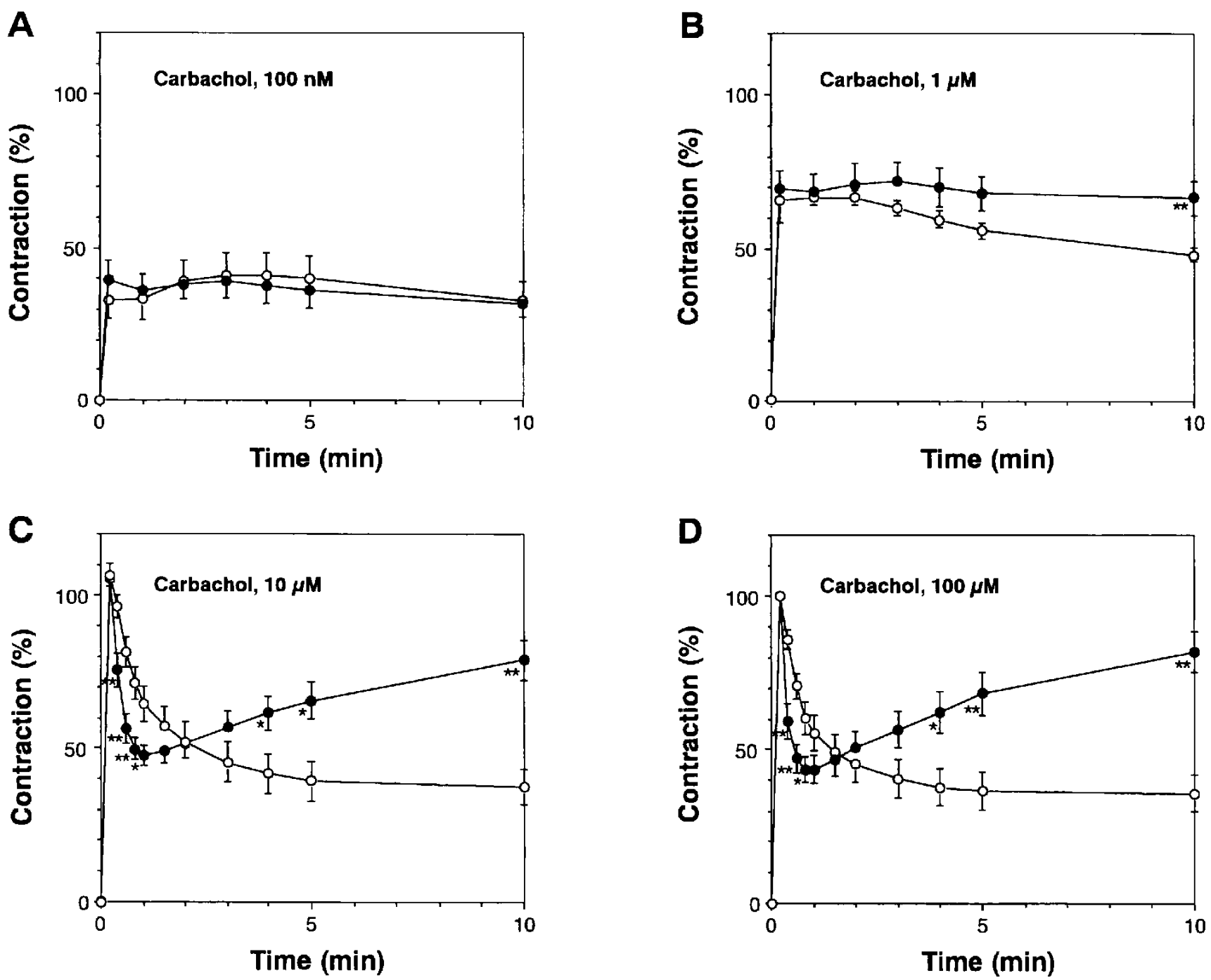

Fig. 2. Time-course of the contraction induced by various concentration of carbachol $(100 \mathrm{nM}-100 \mu \mathrm{M})$ in the muscle pretreated with $3 \mu \mathrm{M}$ phorbol 12 -myristate 13-acetate $(O, n=6)$ or its vehicle $(O, n=8)$ for $24 \mathrm{hr}$ at $37^{\circ} \mathrm{C}$. Each point represents a mean \pm S.E.M. $100 \%$ represents the magnitude of the transient contraction induced by $100 \mu \mathrm{M}$ carbachol. Pretreatment with phorbol ester did not change the magnitude of the transient contraction induced by $100 \mu \mathrm{M}$ carbachol (vehicle control: $147.8 \pm 9.7 \%$ of the contraction induced by $45 \mathrm{mM} \mathrm{K}^{+}, \mathrm{n}=8$; phorbol ester: $145.3 \pm 9.9 \%, \mathrm{n}=6$ ). ${ }^{*}$ and ${ }^{* *}$ : Significantly different from the vehicle value with $\mathrm{P}<0.05$ and $\mathrm{P}<0.01$, respectively. 


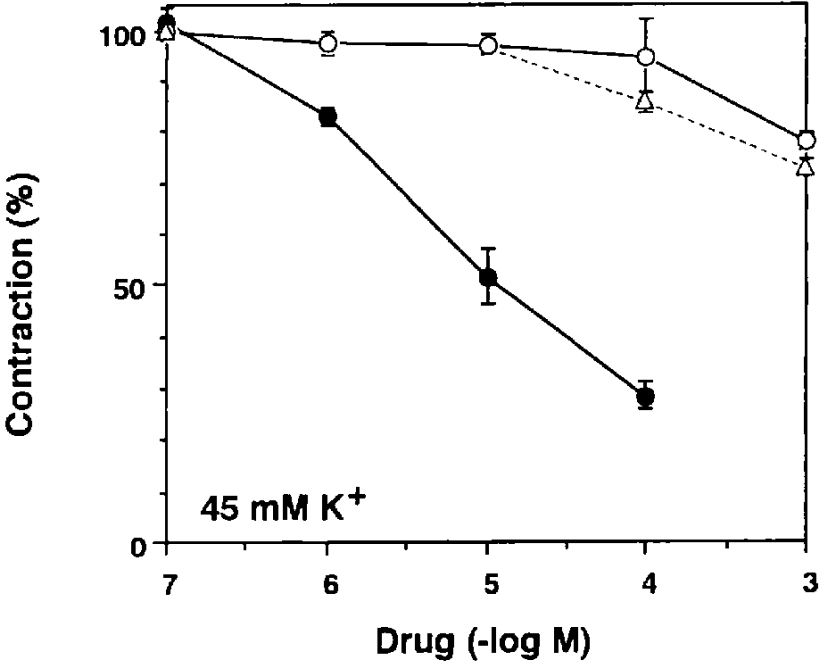

Fig. 3. Concentration-response curves for the inhibitory effects of acetylcholine and carbachol. Acetylcholine $(O)$ or carbachol (O) was added during the sustained contraction induced by $45 \mathrm{mM} \mathrm{K}^{+}$. Diisopropylfluorophosphate $(0.5 \mu \mathrm{M})$ was added $10 \mathrm{~min}$ before the addition of acetylcholine $(\triangle)$. Each point represents the mean \pm S.E.M. of 4 experiments. $100 \%$ represents the muscle tension before the addition of acetylcholine or carbachol.

As shown in Fig. 4A, addition of $100 \mu \mathrm{M}$ carbachol induced a transient increase (to $179.7 \pm 16.5 \%, \mathrm{n}=5$ ) followed by a sustained decrease (to $45.1 \pm 4.5 \%$, at $30 \mathrm{~min}$ ) of the $45 \mathrm{mM} \mathrm{K}^{+}$-induced contraction. In the muscle pretreated with phorbol ester, carbachol also augmented the high $\mathrm{K}^{+}$-induced contraction (to $161.9 \pm 6.2 \%, \mathrm{n}=5$ ). However, the inhibitory effect of carbachol was transient in the muscle pretreated with phorbol ester. The maximum inhibition was reached within 5 min of carbachol application (to $54.6 \pm 5.5 \%$ ), and muscle tension gradually increased thereafter (to $83.9 \pm 6.4 \%$, at $30 \mathrm{~min}$, Fig. 4B).

\section{DISCUSSION}

\section{Different effects of acetylcholine and carbachol}

It has been shown that the contractions induced by acetylcholine and carbachol are mediated by the muscarinic $\mathrm{M}_{3}$-receptor followed by stimulation of the phosphatidilinositol turnover in intestinal smooth muscle (2, 4). We have also reported that both the contractile and relaxant effects of carbachol are due to the activation of $\mathrm{M}_{3}$-receptors sensitive to 4-diphenylacetoxy- $N$-methylpiperidine methiodide (6). Carbachol was more potent than acetylcholine in inducing contraction in guinea pig taenia caeci (present experiment) and rat airway smooth muscles (8). In contrast, acetylcholine was stronger than carbachol in inducing contraction in guinea pig ileum (9) and bovine coronary artery (10). The difference may be due to the difference in the cholinesterase activity in these tissues. In guinea pig taenia caeci, however, Mitchelson and Ziegler (11) suggested that acetylcholine and carbachol interact with different muscarinic receptors since these agonists exhibited different sensitivities towards muscarinic antagonist or $\mathrm{Ca}^{2+}$ channel blockers in the presence of a cholinesterase inhibitor. Takayanagi et al. (12) also showed that there are two types of $\mathrm{M}_{3}$-receptors in the taenia caeci. In the present experiments, we showed that carbachol but not acetylcholine inhibited high $\mathrm{K}^{+}$. induced contraction, and the inhibitory effect of acetylcholine was not augmented in the presence of cholinesterase inhibitor. Carbachol but not acetylcholine may stimulate one of the $\mathrm{M}_{3}$-receptor subtypes that induces muscle relaxation.

\section{Inhibitory effects of carbachol}

In the present experiments, desensitization of protein kinase $\mathrm{C}$ did not modify the effects of a low concentration of carbachol $(100 \mathrm{nM})$, suggesting that protein kinase $\mathrm{C}$ is not involved in this contraction. On the other hand, desensitization of protein kinase $C$ increased the magnitude of sustained contraction induced by $1-100 \mu \mathrm{M}$ carbachol (Fig. 2). These results suggest that high concentrations of carbachol inhibit its own contraction by a protein kinase $\mathrm{C}$-dependent pathway. This suggestion is consistent with the finding that high concentrations of carbachol are necessary to stimulate phosphatidylinositol turnover (2). Sasaguri and Watson (13) have also reported that desensitization of the protein kinase $\mathrm{C}$ activity potentiated the sustained contraction induced by $1 \mu \mathrm{M}$ carbachol in guinea pig ileum. Since phorbol ester activates the voltage-dependent $\mathrm{Ca}^{2+}$ channel in this muscle (14), activation of the membrane $\mathrm{Ca}^{2+}$ extrusion pump (15) may contribute to the carbachol-induced inhibition of its own contraction.

In the presence of $45 \mathrm{mM} \mathrm{K}^{+}$, addition of carbachol $(100 \mu \mathrm{M})$ induced a transient increase followed by a sustained decrease of the contraction (Fig. 4A). In the muscle in which protein kinase $C$ was desensitized, $100 \mu \mathrm{M}$ carbachol only transiently inhibited $45 \mathrm{mM} \mathrm{K}^{+}$-induced contraction (Fig. 4B). These results suggest that high concentrations of carbachol induced transient inhibition of high $\mathrm{K}^{+}$-induced contraction by the protein kinase $\mathrm{C}$ independent pathway and sustained inhibition by the protein kinase $\mathrm{C}$-dependent pathway.

We have previously reported that higher concentrations of carbachol inhibited the increase in cytosolic $\mathrm{Ca}^{2+}$ induced by high $\mathrm{K}^{+}$in the taenia caeci (6). Therefore, the inhibitory effects of carbachol may be due to inhibition of voltage-dependent $\mathrm{Ca}^{2+}$ channels or activation of the membrane $\mathrm{Ca}^{2+}$ extrusion pump. It has been reported that carbachol inhibited the voltage-dependent $\mathrm{Ca}^{2+}$ cur- 


\section{A Vehicle}

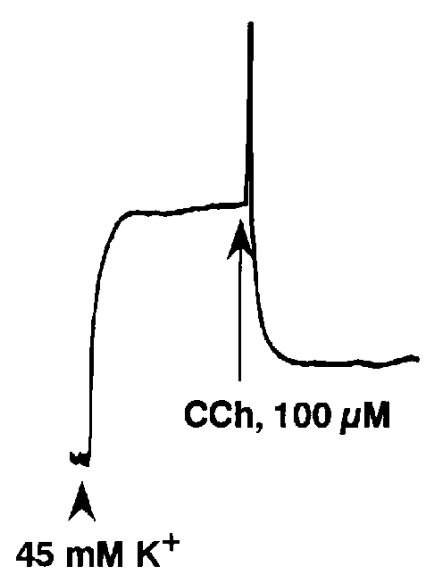

B TPA

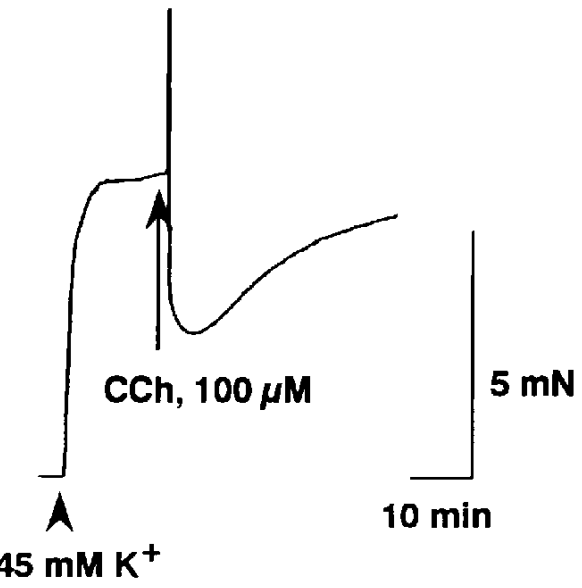

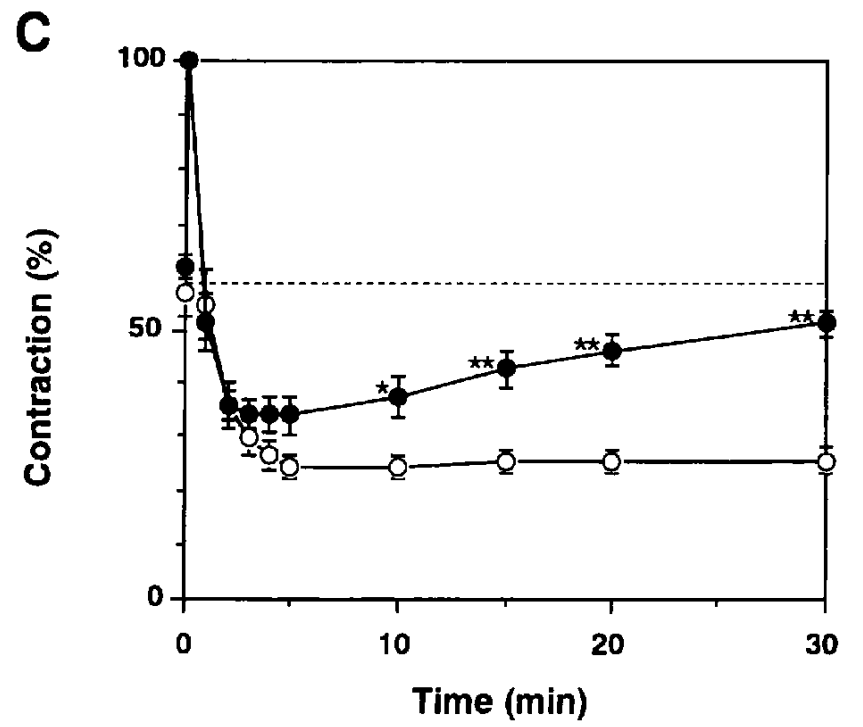

Fig. 4. Effects of $100 \mu \mathrm{M}$ carbachol $(\mathrm{CCh})$ on the $45 \mathrm{mM} \mathrm{K}^{+}$-induced contraction in the muscle pretreated with $3 \mu \mathrm{M}$ phorbol 12-myristate 13-acetate (TPA) (B) or its vehicle (A). C: Time-course of the effects of $100 \mu \mathrm{M}$ carbachol on the high $\mathrm{K}^{+}$-induced contraction in the muscle pretreatment with $3 \mu \mathrm{M}$ phorbol 12-myristate 13-acetate (O) or its vehicle $(\bigcirc)$. $100 \%$ represents the magnitude of the transient contraction induced by $100 \mu \mathrm{M}$ carbachol in the presence of high $\mathrm{K}^{+}$. The magnitude of the contraction induced by $45 \mathrm{mM} \mathrm{KCl}$ before the addition of carbachol was $59.7 \pm 2.6 \%(\mathrm{n}=10)$ ) as shown by the dotted lines. Each point represents the mean \pm S.E.M. of 5 experiments. ${ }^{*}$ and ${ }^{* *}$ : Significantly different from the vehicle value with $P<0.05$ and $\mathrm{P}<0.01$, respectively.

rent in rabbit jejunum (16) and guinea pig ileum (17). Komori and Bolton (18) showed that inositol 1,4,5trisphosphate-induced increase of $\mathrm{Ca}^{2+}$ inactivated the voltage-dependent $\mathrm{Ca}^{2+}$ channel in rabbit small intestine, which might at least partly be responsible for the carbachol-induced decrease of the $\mathrm{Ca}^{2+}$ current. We have previously reported that phorbol ester decreased cytosolic $\mathrm{Ca}^{2+}$ stimulated by high $\mathrm{K}^{+}$in the taenia caeci (7). However, phorbol ester had an excitatory effect on the voltage-dependent $\mathrm{Ca}^{2+}$ current in guinea pig taenia caeci
(14). In addition, phorbol ester had little or no inhibitory effect on the $\mathrm{Ca}^{2+}$ current in the ileum (17). These results suggest that high concentrations of carbachol decrease the voltage-gated $\mathrm{Ca}^{2+}$ current by the protein kinase $\mathrm{C}$-independent pathway, and this may be the reason why carbachol transiently inhibited high $\mathrm{K}^{+}$-induced contraction.

In the muscle in which protein kinase $\mathrm{C}$ was desensitized, addition of $10-100 \mu \mathrm{M}$ carbachol induced a transient increase followed by an immediate decrease of the 
contraction (Fig. 2). When the protein kinase $\mathrm{C}$ activity was desensitized, the decrease of contraction became faster than that in the vehicle-treated muscles (Fig. 2; C and $D$ ). This result suggests that protein kinase $C$ attenuates the transient inhibition induced by carbachol. We have previously reported that activation of protein kinase $C$ by phorbol ester transiently augmented the contraction induced by high $\mathrm{K}^{+}$and carbachol in guinea pig taenia caeci (7). Augmentation of contraction mediated by protein kinase $\mathrm{C}$ may overcome the protein kinase $\mathrm{C}$ independent relaxation induced by carbachol. Another possibility is that activation of protein kinase $\mathrm{C}$ may increase the voltage-dependent $\mathrm{Ca}^{2+}$ current as has been reported (14). However, these mechanisms do not explain why the decrease of $45 \mathrm{mM} \mathrm{K}^{+}$-induced contraction induced by $100 \mu \mathrm{M}$ carbachol in the muscle pretreated with phorbol ester (Fig. 4C) was not faster than that in vehicle-treated strips. Further experiments are necessary to examine these possibilities.

In the present experiments, acetylcholine showed little inhibitory effect, although it may also stimulate the phosphatidylinositol turnover. The subtype of the $\mathrm{M}_{3}$-receptor that is stimulated by acetylcholine may not activate protein kinase $\mathrm{C}$ strongly enough to relax the high $\mathrm{K}^{+}$induced contraction.

In conclusion, it is suggested that high concentrations $(10-100 \mu \mathrm{M})$ of carbachol have dual effects to induce contraction and to inhibit contraction. The inhibitory effect of carbachol is composed of two phases. The sustained relaxation, but not the transient relaxation, may be mediated by the activation of protein kinase $\mathrm{C}$.

\section{Acknowledgment}

This work was supported by a Grant-in-Aid for Scientific Research from the Ministry of Education, Science, Sports and Culture in Japan.

\section{REFERENCES}

1 Bolton TB: Mechanisms of action of transmitters and other substances on smooth muscle. Pharmacol Rev 59, 606-718 (1979)

2 Gardner AL, Choo LK and Mitchelson F: Comparison of the effects of some muscarinic agonists on smooth muscle function and phosphatidylinositol turnover in the guinea-pig taenia caeci. Br J Pharmacol 94, 199-211 (1988)

3 Ozaki H, Zhang L, Buxton ILO, Sanders KM and Publicover NG: Negative-feedback regulation of excitation-contraction coupling in gastric smooth muscle. Am J Physiol 263, C1160-C1171 (1992)
4 Honda K, Takano $\mathrm{Y}$ and Kamiya $\mathrm{H}$ : The mechanism of muscarinic agonist-stimulated inositol phosphate formation in permiabilized ileal smooth muscle. Jpn J Pharmacol 65, 275-280 (1994)

5 Somlyo AV, Bond M, Somlyo AP and Scarpa A: Inositol triphosphate-induced calcium release and contraction in vascular smooth muscle. Proc Natl Acad Sci 82, 5231 - 5235 (1985)

6 Mitsui $M$ and Karaki $H$ : Dual effects of carbachol on cytosolic $\mathrm{Ca}^{2+}$ and contraction in intestinal smooth muscle. Am J Physiol 258, C787-C793 (1990)

7 Mitsui $M$ and Karaki H: Contractile and relaxant effects of phorbol ester in the intestinal smooth muscle of guinea-pig taenia caeci. Br J Pharmacol 109, 229-233 (1993)

8 Vornanen $\mathrm{M}$ and Tirri R: Cholinergic responses in different sections of rat airways. Acta Physiol Scand 113, 177-182 (1981)

9 Nakajyo S, Shimizu K, Kometani A, Kato K, Kamizaki J, Isogai $A$ and Urakawa N: Inhibitory effect of bassianolide, a cyclodepsipeptide, on drug-induced contractions of isolated smooth muscle preparations. Jpn J Pharmacol 32, 55-64 (1982)

10 Duckles SP: Vascular muscarinic receptors: pharmacological characterization in the bovine coronary artery. J Pharmacol Exp Ther 246, 929-934 (1988)

11 Mitchelson FM and Ziegler A: The effect of gallamine, gallopamil and nifedipine on responses to acetylcholine and carbachol in the taenia of the guinea pig caecum. Br J Pharmacol 83, 145-155 (1984)

12 Takayanagi I, Hisayama T, Kiuchi Y and Sudo H: Propylbenzilylcholine mustard discriminates between two subtypes of muscarinic cholinoceptors in guinea-pig taenia caecum. Arch Int Pharmacodyn Ther 298, 210-219 (1989)

13 Sasaguri $\mathrm{T}$ and Watson SP: Protein kinase $\mathrm{C}$ regulates the tonic but not the phasic component of contraction in guinea-pig ileum, Br J Pharmacol 98, 791-798 (1989)

14 Obara $\mathrm{K}$ and Yabu $\mathrm{H}$ : Modulation of voltage-dependent calcium channel activity by phorbol ester and phosphatase inhibitors. Jpn J Pharmacol 58, Supp II, 407P (1992)

15 Furukawa $\mathrm{K}$, Tawada $\mathrm{Y}$ and Shigekawa $\mathrm{M}$ : Protein kinase $\mathrm{C}$ activation stimulates plasma membrane $\mathrm{Ca}^{2+}$ pump in cultured vascular smooth muscle cells. J Biol Chem 264, 4844-4849 (1988)

16 Russel SN and Aaronson PI: Carbachol inhibits the voltagegated calcium current in smooth muscle cells isolated from the longitudinal muscle of the rabbit jejunum. J Physiol (Lond) 426, 23P (1990)

17 Unno $\mathrm{T}$, Komori $\mathrm{S}$ and Ohashi $\mathrm{H}$ : Inhibitory effect of muscarinic receptor activation on $\mathrm{Ca}^{2+}$ channel current in smooth muscle cells of guinea-pig ileum. J Physiol (Lond) 484, 567-581 (1995)

18 Komori S and Bolton TB: Inositol trisphosphate releases stored calcium to block voltage-dependent calcium channels in single smooth muscle cells. Pfiugers Arch 418, 437 - 441 (1991) 